\title{
夏だいだいの苦味に関する研究（第 1 報）
}

\author{
フラボノイドの系統別周年経過と加工条件の検討
}

松 永 昌 司*田坂, 利 人 $^{*}$

従来の夏だいだいは生果のみを対照として育生され， その特有のそうかいな酸味，風味，適度な甘味が好ま れ，現在ではジュース原料として需要の伸びは著しいも のがあるが，その成分に苦味が多く，種子の多いことな ぞ加工上種々欠阫があり，加工面における発展を阻害し ているので，生果だけでなく，加工にる適した苦味成分 の少ない采統を得ることが必要となって来た。

柑橘類の苦味については最近各方面より研究されてお 句，苦味成分中，フラボノイド色素（とくにナリンギ

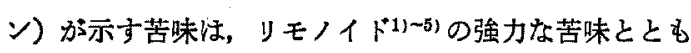
にもっとも関心をもたれるものであるが,フラボノイド に関しては，近年䤏素による脱苦味処理の方向に研究が 進められ，野村4)，中林6)，福本")らによる報告が見られ る。リモノイドについての脱苦味は未知な点が多く、物 理的にも，化学的にも未解決であり，栽培面において KEFFODら ${ }^{3 / 3)}$ により，種なな台木を用い苦味（主として リモノイド)の少ない相桶類を得ようとする試みがなさ れている程度である。また従来より柑㰌類については， 芽条变異による優良系統の選报試験が各所で進められ ているが，夏だいだいについても，苦味成分の少ない系 統がこれによって得られるのではないかと予測されつつ も，いまだこのような報告は見られない。

そこで著者らは現在存在する夏だいだいの各系統》に つき，そのフラポノイドを，果肉中および推汁中に分け て周年経過を調查し，さらに熟期，種子数，果汁歩合な どにつき加工用としての条件をあわせて検討し， 2,3 の知見を得たのでここに報告する。

\section{試料およひ実験方法}

山口県萩市堀内，萩市柑㛢試駼場國場において，1956 年キュク台に接木したものを，翌 1957 年春, $100 \mathrm{~cm} \times$
$200 \mathrm{~cm}$ 間隔に植え, 10 アール当り窒素 $30 \mathrm{~kg}$, リン酸 $25 \mathrm{~kg}$ ，加里 $28 \mathrm{~kg}$ を年 3 回江分けて施肥した 5 年生 夏 だいだいの 41 系統 $^{81}$ につき，1961 年 12 月より翌 1962 年 5 月まで毎月 1 回定期的に，同一果径のものを，3 個 ずつ探取し分析を行なった。

全糖および酸は常法により行ない，フラボノイドは DAVIS ${ }^{9}$ 法により Beckmann 型分光々電比色計を使用 し，10 $\mathrm{mm}$ のセルを用い，波長 $420 \mathrm{~m} \mu$ で測定，ナリ ソギン量として mg\% で表示した。すなわち，振汁中 のフラボノイドは，制皮後海綿状部分をできるだけ除去 した果実を㩁汗し，冷却管を付して湯浴上に $85^{\circ} \mathrm{C} ， 30$ 分処理したるのを用い，果肉中のフラボノイドについて は，前記携计液を全果汗量として計量したのち，全汁液 の $1 / 4$ と同じく全摍汗残渣の $1 / 4$ をとり，4分間ミキ廿 一で磨碟し，㩁汗中の場合と同様 $85^{\circ} \mathrm{C}, 30$ 分間処理し たのち，搾汗液，果肉磨砕液のいずれもそのフラポノイ

ド含量が $40 \mathrm{mg} \%$ 以下になるよら希釈 調整後沪別し， 両者とも $0.2 \mathrm{cc}$ を取って, $10 \mathrm{cc}$ の $90 \%$ ジエチンング リ $=ー ル, 0.2 \mathrm{cc}$ の $4 \mathrm{~N}-\mathrm{NaOH}$ を加光, $30^{\circ} \mathrm{C}, 30$ 分 間放置後,ナリンギン検量曲線により比色定量した。

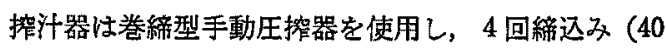
分間)を行なった（第 1 表)。

㩁汁歩合は果肉重に対する\%で示した。さらに，供試 澍が若木であるため，対照区として約 60 年生の在来種 についてる平行して調查を行なった。

\section{実験結果と考察}

\section{1. 熟期の早晚}

加工面より各系統の夏だいだいを見る場合，苦味の少 ないことは必須条件であるが，さらに熟期早く，果汁歩 合が高く，種子数す少なく，しかす早くス上り10111)*゙

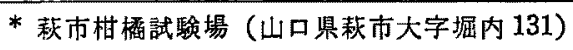

Studies on the Bitterness of Natudaidai. Part I. Examination of seasonal variation of flavonoid on use strains and its utilizational condition. By Masasi Matunaga and Tosito Tasaka.

**水りとは，春から复にかけて砂じょう(果肉の粒)が白っぽく，色があせて，果汁が極端に少なくなって硬くな り，食味がいちじるしく悪くなるるのをいい，三宝柑，ボンカン，夏だいだいなど各産地で相当ひどい被害をう けているが，いまだ完全な対策は見られない。 
ないことが望ましい。

そこでこれらにつき便宜上，早生柑，中生柑，晚生柑

第 1 表 巻繶型手動圧㩲器を使用したときの摧汁率 とフラボノイド溶出率の関係

\begin{tabular}{|c|c|c|}
\hline 㧒计歩合 & $\begin{array}{l}\text { フラポノイド } \\
\text { 溶出 率 }\end{array}$ & 備 \\
\hline $100.0^{\%}$ & $100.0^{\%}$ & \multirow{2}{*}{$\begin{array}{l}\text { 手動式搾计器で, } \\
300 \text { 分 } 9 \text { 場盒 } \\
\text { 同上約 } 37 \text { 分 }\end{array}$} \\
\hline 94.5 & 87.2 & \\
\hline 91.7 & 85.8 & 同上約 22 分 \\
\hline 86.6 & 77.7 & 同上約 12 分 \\
\hline 78.3 & 51.1 & 同上約 5 分 \\
\hline 75.4 & 40.9 & 手搾りの場合 \\
\hline
\end{tabular}

注：果肉の最高控汁量を $100 \%$ としそのとき溶出され たフラボノイドを $100 \%$ に見たときの比率で，果 実によっては控汁歩合やフラボノイド合有量が異 なるのでそれぞれ最高のときをもって $100 \%$ にす る.
の3 種に熟期を区分して調查した。従来この区別法につ いては一定でないので，仅に食用適期の酸度 $2.0 \%$ 以下， 糖分比（全糖％/酸\%） 3.0 以上の值に至った時期を以 て区分し検討した。区分の絬果は第 2 表に示すごとく， その時期が 1 2月の6采統は早生柑， $3 \sim 4$ 月の 29 系統は中生柑，5月以降を脕生柑とし 7 系統（在来種を 含む)であった。

\section{2. 果汁步合}

第3表において見られるように，熟期の早い系統中， 果汁路合が急減しないすのは 1. Dで， $72 \sim 74 \%$ 程度の 值を示しその周年経過に大きい変化は見られないか゚， B. 1 は 2 月に $73 \%$ で自後除々に降下し，1.Dのそれよ り劣って来ている。中生柑では 304, 21，T.G. 186， O. 186 が 71〜76\%程度の高い経過定し, 愛知, 柑試. 1 がこれにうぐ。晚生柑ではとくに滝原，谷川が優れ， M. 167のみに果汁の急隇が見られるが，いずれる高歩合 を示し他の早生柑および中生柑よりも4，5月における

第 2 表 食用適期とその酸度抒よび糖分比

\begin{tabular}{|c|c|c|c|c|c|c|c|c|c|}
\hline \multirow{2}{*}{ 熟期区分 } & \multirow{2}{*}{ 系 統 名 } & \multicolumn{2}{|c|}{ 可 } & \multicolumn{2}{|c|}{ 食期 } & \multirow{2}{*}{ 系 統 名 } & 可 & \multicolumn{2}{|c|}{ 食期 } \\
\hline & & 月 & 酸 & 度 \% & 糖 分 比 & & 月 & 酸 度 \% & 糖 分比 \\
\hline \multirow{3}{*}{ 早生柑 } & 12 & 1 & & 1.5 & 3.8 & \multirow{3}{*}{$\begin{array}{c}\text { 川野系 } \\
\text { 网 辰 } \\
\text { A. } 1\end{array}$} & 1 & 1.4 & 4.3 \\
\hline & B. 1 & 1 & & 1.8 & 3.0 & & 2 & 1.6 & 4.1 \\
\hline & 1. D & 1 & & 1.7 & 3.0 & & 1 & 1.7 & 4.1 \\
\hline \multirow{14}{*}{ 中生柑 } & 409 & 4 & & 1.8 & 3.1 & \multirow{3}{*}{$\begin{array}{c}\text { 吉 村 } \\
\text { 福 田 } \\
\text { O. } 186\end{array}$} & 4 & 1.8 & 3. 2 \\
\hline & 302 & 3 & & 1.5 & 3.4 & & 4 & 1.5 & 3.4 \\
\hline & 422 & 4 & & 1.7 & 3.5 & & 4 & 1.5 & 3.8 \\
\hline & 21 & 4 & & 1.9 & 3.0 & 3 & 4 & 1.6 & 3.4 \\
\hline & M. 186 & 4 & & 1.4 & 3.7 & 396 & 4 & 1.8 & 3.2 \\
\hline & 380 & 4 & & 2.0 & 3.1 & 447 & 4 & 1.5 & 3.8 \\
\hline & 434 & 4 & & 1.7 & 3.3 & \multirow{2}{*}{$\begin{array}{c}\text { T. G. } 186 \\
142\end{array}$} & 4 & 1.6 & 3.4 \\
\hline & 436 & 4 & & 1.3 & 4. 0 & & 4 & 1.6 & 3. 4 \\
\hline & 小野村 & 4 & & 1.4 & 3.9 & 188 & 4 & 1.4 & 4. 0 \\
\hline & 2 & 4 & & 1.6 & 3.7 & 285 & 4 & 1.5 & 3. 6 \\
\hline & 小 林 & 4 & & 1.9 & 3.1 & \multirow{2}{*}{$\begin{array}{l}\text { 愛 知 } \\
\text { 柑試. } 1\end{array}$} & 4 & 1.9 & 3.0 \\
\hline & 62 & 4 & & 2.0 & 2.9 & & 4 & 1.9 & 3.3 \\
\hline & 211 & 4 & & 1.7 & 3.7 & \multirow{2}{*}{$\mid \begin{array}{c}\text { 垏 守 } \\
\text { 传々亚および } \\
5\end{array}$} & 4 & \multirow{2}{*}{\multicolumn{2}{|c|}{$\begin{array}{rr}1.8 & 3.6 \\
(2 \text { 月以前不可 }) \\
\end{array}$}} \\
\hline & 304 & 4 & & 1.4 & 4.0 & & $4 ?$ & & \\
\hline \multirow{4}{*}{ 晚生标 } & 22 & 5 & & 1.5 & 3.1 & \multirow{4}{*}{$\begin{array}{ll}\text { 滝 } & \text { 原 } \\
\text { 谷 } & \text { 川 } \\
\text { 野 } & \text { 村 }\end{array}$} & 5 & \multirow{4}{*}{$\begin{array}{l}1.7 \\
2.0 \\
2.0\end{array}$} & 3.3 \\
\hline & M. 167 & 5 & & 1.6 & 2.8 & & 5 & & 3.0 \\
\hline & 大 川 & 5 & & 1.5 & 3.0 & & 5 & & 3.0 \\
\hline & 在来種 & 5 & & 1.9 & 3.0 & & & & \\
\hline
\end{tabular}

注：食用適期は 12 月以降の酸度 $2 \%$ 以下，糖分比（全桾％/酸度\%）3.0以上とした，熟期の区分は $1 \sim 2$ 月它早 生, $3 \sim 4$ 月を中生，5月以降を睍生柑とした。 
第3表系統別㵠汁歩合

\begin{tabular}{|c|c|c|c|c|c|c|c|c|}
\hline 熟期区分 & 系統名 & $\begin{array}{l}\text { 最倠 } \\
\text { 区分 }\end{array}$ & $\begin{array}{l}\text { 果肉重に対する } \\
\text { 果汁量\%の筙囲 }\end{array}$ & 備 & 秝統名 & $\begin{array}{l}\text { 最低 } \\
\text { 区分 }\end{array}$ & $\begin{array}{l}\text { 果肉重に対する } \\
\text { 果汁量\%の笧囲 }\end{array}$ & 考 \\
\hline \multirow{3}{*}{ 早生柑 } & 12 & & $72.1-66.2$ & \multirow[t]{3}{*}{$\begin{array}{l}\text { ただし } 4 \text { 月ま } \\
\text { での值 }\end{array}$} & \multicolumn{2}{|l|}{ 川野系 } & $76.4-66.9$ & $\begin{array}{l}\text { ただし } 4 \text { 月ま. } \\
\text { での值 }\end{array}$ \\
\hline & B. 1 & B & $73.0-65.6$ & & 岡 辰 & A & $74.6-57.4$ & $\begin{array}{rl}* & 4 \text { 月 } 71.3 \% \\
& 5 \text { 月 } 57.4 \% .\end{array}$ \\
\hline & 1. $\mathrm{D}$ & D & $74.5-72.3$ & & A. 1 & A & $86.1-60.9$ & $\begin{array}{l}* 4 \text { 月 } 74.1 \% \\
5 \text { 月 } 70.2 \%\end{array}$ \\
\hline \multirow{15}{*}{ 中生柑 } & 409 & A & $78.9-53.8$ & $\begin{array}{r}* 4 \text { 月 } 71.5 \% \\
5 \text { 月 } 53.8 \%\end{array}$ & 福 田 & A & $75.8-59.5$ & $\begin{array}{r}* 4 \text { 月 } 68.6 \% \\
5 \text { 月 } 59.5 \%\end{array}$ \\
\hline & 302 & & $78.7-72.2$ & $\begin{array}{l}\text { ただし } 4 \text { 月ま } \\
\text { での值 }\end{array}$ & 0.186 & $\mathrm{D}$ & $75.0-71.1$ & \multirow{3}{*}{$\begin{array}{l}\text { ただし } 2 \text { 月ま } \\
\text { での值 }\end{array}$} \\
\hline & 422 & $B$ & $74.2-62.6$ & \multirow[t]{2}{*}{$\begin{array}{l}\text { * } 4 \text { 月 } 73.7 \% \\
5 \text { 月 } 62.6 \%\end{array}$} & 5 & & $80.5-71.7$ & \\
\hline & 21 & $\mathrm{D}$ & $76.4-73.3$ & & 㝾々亚 & & $87.5-74.5$ & \\
\hline & M. 186 & B & $75.1-65.5$ & $\begin{array}{rl}* & 4 \text { 月 } 73.3 \% \\
& 5 \text { 月 } 65.5 \%\end{array}$ & 3 & A & $76.3-55.6$ & $\begin{array}{rl}* & 4 \text { 月 } 70.9 \% . \\
5 & \text { 月55. } 6 \%\end{array}$ \\
\hline & 380 & & $75.7-74.4$ & $\begin{array}{l}\text { たたし } 4 \text { 月ま } \\
\text { での値 }\end{array}$ & 396 & A & $75.5-58.4$ & $\begin{array}{l}* 4 \text { 月 } 69.4 \% . \\
5 \text { 月 } 58.4 \%\end{array}$ \\
\hline & 434 & B & $76.4-61.1$ & $\begin{array}{rl}* & 4 \text { 月 } 76.4 \% \\
& 5 \text { 月 } 61.1 \%\end{array}$ & 447 & A & $75.3-55.7$ & $\begin{array}{l}* 4 \text { 月 } 70.8 \% \\
5 \text { 月 } 55.7 \% \text {, }\end{array}$ \\
\hline & 436 & $\mathrm{~B}$ & $76.6-63.2$ & * 4 月 $72.7 \%$ & $\begin{array}{r}\text { T. G. } \\
\quad 186\end{array}$ & D & $74.2-71.8$ & \\
\hline & 小野村 & A & $74.6-56.4$ & $\begin{array}{l}4 \text { 月 } 56.4 \% \\
5 \text { 月 } 61.4 \%\end{array}$ & 142 & B & $73.3-64.4$ & $\begin{array}{l}* 4 \text { 月 } 71.1 \% . \\
5 \text { 月 } 64.4 \% .\end{array}$ \\
\hline & 2 & C & $74.5-68.1$ & & 188 & A & $75.6-54.5$ & * 4 月 $71.2 \%$. \\
\hline & 小 林 & B & $74.8-65.0$ & $\begin{array}{rl}* & 4 \text { 月 } 74.8 \% \\
5 & \text { 月 } 65.0 \%\end{array}$ & 285 & $\mathrm{~A}$ & $74.9-57.4$ & $\begin{array}{l}4 \text { 月 } 66.6 \% \\
5 \text { 月 } 57.4 \%\end{array}$ \\
\hline & 62 & $\mathrm{C}$ & $77.3-66.2$ & $\begin{array}{l}* 4 \text { 月 } 77.1 \% \\
5 \text { 月 } 66.2 \%\end{array}$ & 票 知 & $\mathrm{C}$ & $80.7-70.9$ & \\
\hline & 211 & $\mathrm{C}$ & $77.2-67.8$ & $\begin{array}{r}* 4 \text { 月 } 77.2 \% \\
5 \text { 月 } 67.8 \%\end{array}$ & 柑試. 1 & $\mathrm{C}$ & $78.4-70.2$ & \\
\hline & 304 & $\mathrm{D}$ & $76.6-73.6$ & & 津 森 & B & $79.8-61.6$ & $\begin{array}{r}* 4 \text { 月 } 72.7 \% \\
5 \text { 月 } 61.6 \%\end{array}$ \\
\hline & 吉 村 & B & 75. $4-64.1$ & $\begin{array}{r}* \quad 4 \text { 月 } 74.0 \% \\
5 \text { 月 } 64.1 \%\end{array}$ & & & & \\
\hline & 22 & $\mathrm{C}$ & $77.3-70.4$ & & 滝 原 & D & $79.1-73.4$ & \\
\hline & M. 167 & B & $79.6-62.4$ & $\begin{array}{r}* 4 \text { 月 } 71.8 \% \\
5 \text { 月 } 62.4 \%\end{array}$ & 谷 川 & D & $78.8-73.8$ & \\
\hline 䀨生不 & 大 川 & $\mathrm{C}$ & $73.5-66.8$ & ホボ 1 1054年 & 野 村 & $\mathrm{C}$ & 78. $1-69.9$ & \\
\hline & 在来種 & & $71.6-69.9$ & $\begin{array}{l}\text { 平均傎 } \\
\text { 年 }\end{array}$ & 在来種 & $\mathrm{C}$ & $71.9-67.9$ & $\begin{array}{l}\text { ただし1961年 } \\
\text { 〜1962年の值 }\end{array}$ \\
\hline
\end{tabular}

注：*印注 5 月急減，**印は 4 月より急減したものを示す。

(1961年12月～1962年 5 月)

\begin{tabular}{c|ccccc}
\hline 最低搾汁步合の区分 & $61.0 \%$ 以下 & $61.1 \sim 66.0 \%$ & $66.1 \sim 71.0 \%$ & $71.1 \%$ 以上 \\
\hline 符 & 是 & $\mathrm{A}$ & $\mathrm{B}$ & $\mathrm{C}$ & $\mathrm{D}$ \\
\hline
\end{tabular}


果汁量は安定し，変化は少ないようである。全般的に見 $て ， 4 \sim 5$ 月における果汁步合の急減がめだつ最大の原 因は，供試樹が若木であったためと考えられる。

晚生相滝原は果肉が柔らかく，搾汁した場合きわめて 线渣量が少ない特徵を有し，果汁工業原料としては良系 統港属するものと思われる。このととはつぎのごとき搾 汁操作の関係上なおさらであるといえよう。すなわち， 㧧汗步合は, 試験に使用した巻締型手動圧售器 の操作 をフフラボノイド定量の都合上，第 1 表のごとく擦汁量 と果汁中に溶出するフラボノイド量が，大体平行となる 40分付近まで挨计した結果の数值であり，連続瞬間挨汁 法を採用する工場にあっては，第 3 表に揭げた数值より も低いことが予想されるためである。

\section{3. 果肉歩合および種子数}

果肉歩合については，各䒺統とも全果重量に対し60～ ～69\%程度でいずれも大差なく,薄皮の特徽をる 12 の みが，76\%前後でもっともすぐれていた。

種子数については，各柔統とも極端に少ないものは見 られず，第 4 表のとおりもっとも少ないものは，果実 1 コ当り平均 19 22 コで，12，川野系，A. 1，188，302， 422, 潼原の 7 系統であり，23 25=のもの 5 系統, 25.5 コ以上のもの 29 采統で, もっとも多いものは在来
種，津森，野村のそれぞれ 34.8 コ，35.5コ，34.6コな ぞで, 在来種の種子数恃 29 から 40 の篹团にちらばって いる。

\section{4. 苦 味 量}

控汁中および果肉中のフラボノイド量測定結果は，第 5 表および第 6 表で明らかなように，その周年経過は非 常にはげしい変動を示し，食用に適さない1 月以前を除 き， $1 \sim 2$ 月に急増するるのと，4〜5月に急增する 2 と打りの傾向が見られ，全般的炕過熟期炕ると減少卞 る傾向が強い。これは KEFFOD ら゙のの行なったリモノイ ドの実験結果と同一傾向である。

(1) 搾汁中のフラボノイド

味賞江苦く感じる果汗中のナリンギンは，最低含有 量が $30 \mathrm{mg} \%$ 内外であるため, この量に近い系統が得 られることを期待したが，搾汁方法の関係もあり，過熟 期以外にそのような少ないるのは認められなかった。し かし第 1 表により，さきに㩁汁歩合の項で述べたよう に，実際に工場で搾计される場合，長時間摧汁は行なる れないので，第 5 表に示された数値の 50 ～ $55 \%$ 程度の フラボノイド溶出量，すな方ち最高 $70 \mathrm{mg} \%$ ，最低 30 $\mathrm{mg} \%$ 前後であると考えてさしつかえないであるう。さ らには，第 7 表に示すよらに，工場における㩁汁機の種

第 4 表 系統別 種子数

\begin{tabular}{|c|c|c|c|c|c|c|c|c|c|c|c|c|}
\hline 熟期区分 & 系統名 & 区分 & 平均 & 範 因 & 系統名 & 区分 & 平均 & 範 囲 & 系統名 & 区分 & 平均 & 㹊 囲 \\
\hline \multirow{2}{*}{ 早 生 柑 } & 12 & A & 20.4 & $19-30$ & B. 1 & $\mathrm{C}$ & 27.4 & $24-31$ & 1. $\mathrm{D}$ & $\mathrm{C}$ & 27.0 & $24-31$ \\
\hline & 川野系 & A & 20.3 & $17-26$ & 岡 辰 & $\mathrm{C}$ & 27.3 & $23-33$ & A. 1 & A & 21.3 & $14-31$ \\
\hline \multirow{10}{*}{ 中 生 柑 } & \multirow{5}{*}{$\begin{array}{r}21 \\
\text { M. } 186\end{array}$} & $\mathrm{C}$ & 29.0 & $24-33$ & 小 林 & $\mathrm{C}$ & 31.6 & $27-37$ & 396 & B & 23. 6 & $16-32$ \\
\hline & & A & 19.0 & $15-23$ & 62 & B & 25.4 & $19-29$ & \multirow{3}{*}{$\begin{array}{c}447 \\
\text { T. G. } \\
186 \\
142\end{array}$} & $\mathrm{C}$ & 26.3 & $15-33$ \\
\hline & & A & 21.4 & $15-26$ & 211 & $\mathrm{C}$ & 27.1 & $19-33$ & & B & 25.4 & $20-32$ \\
\hline & & B & 25.6 & $22-32$ & 304 & B & 25.4 & $21-29$ & & B & 24.2 & $19-29$ \\
\hline & & $\mathbf{B}$ & 26.0 & $21-29$ & \multirow{2}{*}{$\begin{array}{ll}\text { 吉 村 } \\
\text { 福 } \text { 田 }\end{array}$} & $\mathrm{C}$ & 31.6 & $26-38$ & 188 & A & 21.4 & $16-25$ \\
\hline & 380 & $\mathrm{C}$ & 28.0 & $26-32$ & & $\mathrm{C}$ & 28.7 & $23-37$ & \multirow{5}{*}{$\begin{array}{l}\text { 要 知 } \\
\text { 朴試. } 1 \\
\text { 津 橉 }\end{array}$} & C & 28.3 & $24-32$ \\
\hline & 434 & B & 22.8 & $14-31$ & 0.186 & $\mathrm{C}$ & 31.5 & $26-37$ & & B & 23.4 & $16-28$ \\
\hline & 436 & C & 29.0 & $25-32$ & 5 & $\mathrm{C}$ & 26.9 & $21-37$ & & B & 25.3 & $20-29$ \\
\hline & 小野村 & $\mathrm{C}$ & 28.3 & $25-36$ & 佐々立 & $\mathrm{C}$ & 28.4 & $25-32$ & & $\mathrm{C}$ & 36.7 & \multirow[t]{2}{*}{$33-37$} \\
\hline & 2 & $C$ & 30.0 & $22-32$ & 3 & C & 27.7 & $24-31$ & & & & \\
\hline \multirow{3}{*}{ 晚 生 柎 } & 22 & $\mathrm{C}$ & 26.8 & $24-29$ & 原 & A & 21.5 & $16-35$ & \multirow[t]{3}{*}{ 在来種 } & \multirow[t]{3}{*}{$\mathrm{C}$} & 34.8 & \multirow[t]{3}{*}{$29-40$} \\
\hline & M. 167 & $\mathrm{C}$ & 27.6 & $21-32$ & 谷 川 & C & 27.8 & $23-36$ & & & & \\
\hline & 大 川 & B & 23.8 & $20-30$ & 野 村 & $\mathrm{C}$ & 34.6 & $31-38$ & & & & \\
\hline
\end{tabular}

注:

\begin{tabular}{|c|c|c|c|}
\hline 平均種子数の区分 & $19.0-22.5=$ & $22.6-26.0=$ & $26.1 \sqsupset$ 以上 \\
\hline 符 & A & B & C \\
\hline
\end{tabular}




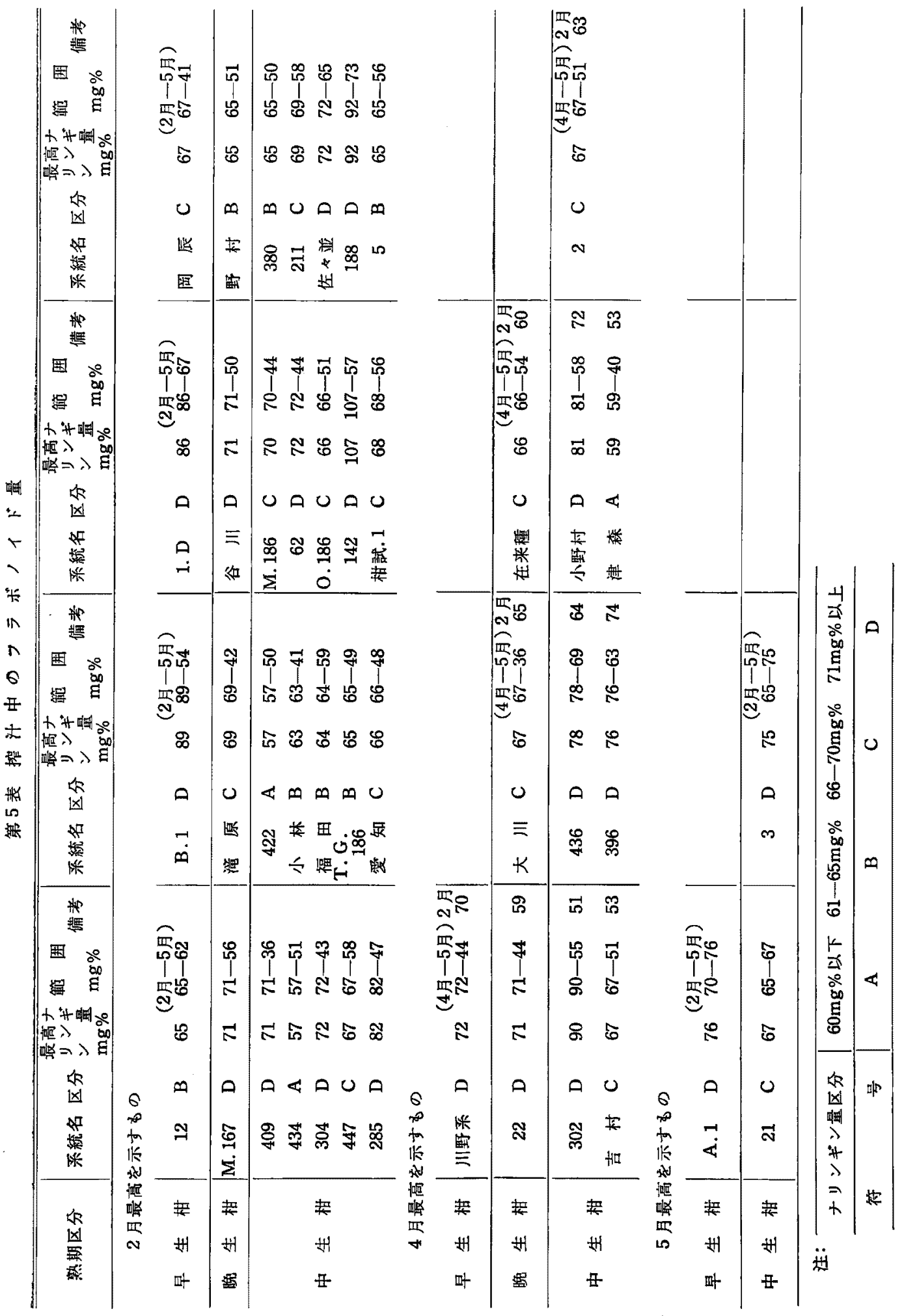




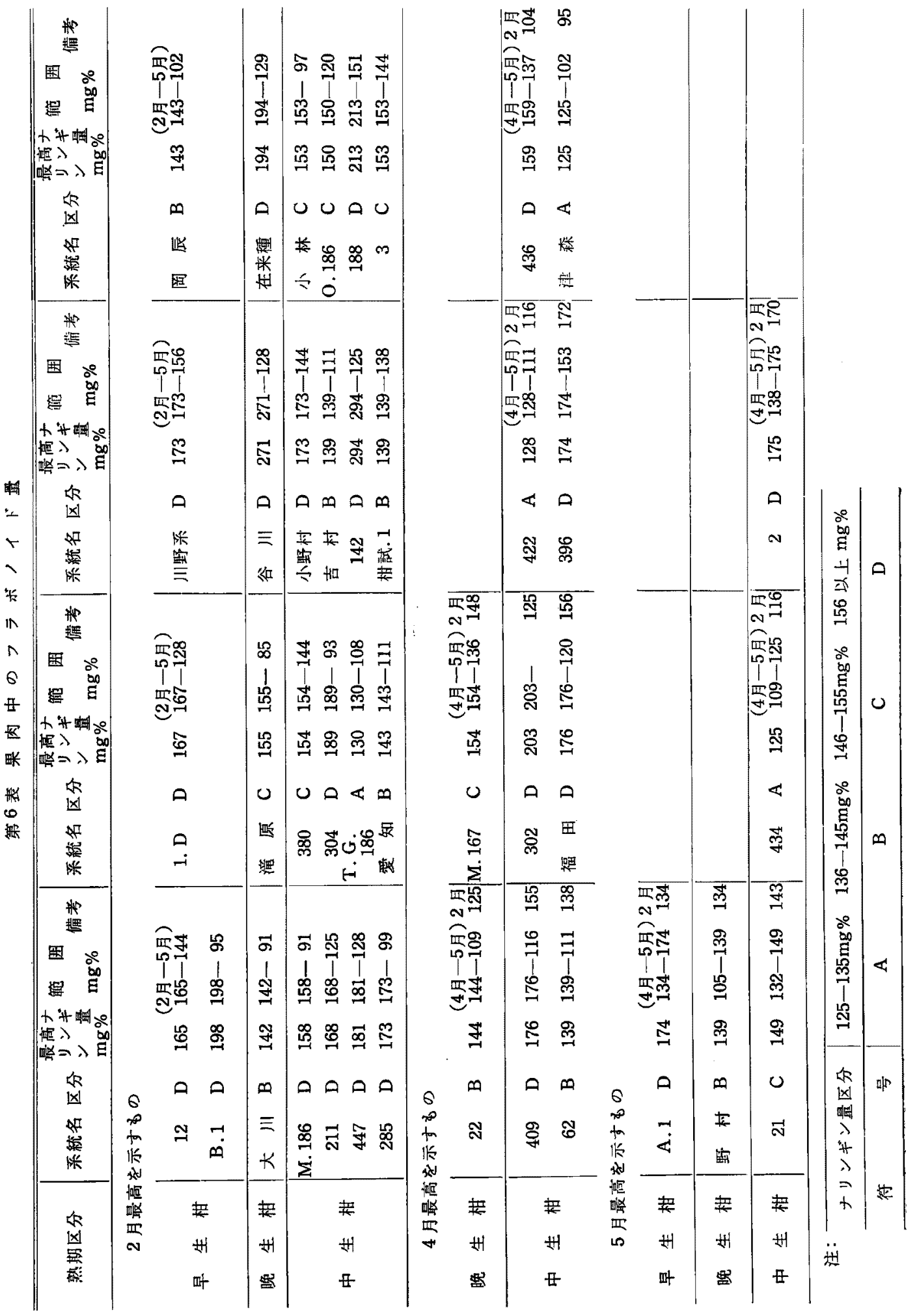


第 7 表 搾计菠と溶出フラボノイド量の工埸例

\begin{tabular}{|c|c|c|c|c|c|c|}
\hline \multirow{2}{*}{\multicolumn{2}{|c|}{ 搖汁区全 }} & 福 & \multicolumn{2}{|l|}{ 本 ${ }^{7}$} & \multicolumn{2}{|c|}{ 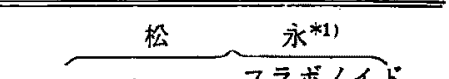 } \\
\hline & & 搾汁歩合 & 苦 & 眛 & 㧒汁步合（ナ少 & 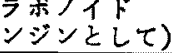 \\
\hline 夏み加え果汁量 & & $40 \sim 42 \%$ & & & $\begin{array}{c}\% \\
47.7^{* 21}\end{array}$ & $\mathrm{mg} \%$ \\
\hline 擭 & 1 番果汁 & $\begin{array}{l}\text { (機型不明) } \\
25 \sim 28\end{array}$ & 無 & & $\begin{array}{c}(\text { キャタビラ式 }) \\
27\end{array}$ & 75.1 \\
\hline 搾 & 1 番果汁 & - & - & & $\begin{array}{l}(\sqcap-タ リ ー フ ゙ レ ッ \\
シ+-) 31\end{array}$ & 55.0 \\
\hline 遠心分蜼 & 2 番果汁 & $5 \sim 10$ & 有 & & - & - \\
\hline ペルプクラッシャー & 3 番果汁 & $5 \sim 10$ & 有 & & 8 & 227.5 \\
\hline
\end{tabular}

注: *1) N工場の製品による(2月 5 日測定).

*2）萩市における 5 力年平均值（2 月上旬の）ただし，巻締器による数值を示す.

類および操作条件などによっては，㩁汁歩合を高くして む，フラポノイドの溶出量を抑制することは可能である 5 。

早生相㧍よび晚生柑のフラボノイド量は，摍汁中では いずれも多い值を示し，中生柑のみ少なく認められた が，フラボノイド生成に地域差”のあることが考光られ るので，暖い地域では早生柑などる本実験供試料が示し た数值より，少ない結果が得られる可能性は多分にある う。

各系統の搾汁中フラボノイド量のもっとも少ないもの は中生柑の $422 ， 434$ ，津森で $60 \mathrm{mg} \%$ 以下を 示 し，こ れにつぐものとして 12, 小林, T.G.186，福田，5，野 村，380などが見られる。它た，早生柑の B.1，川野系 などは 5 月に入ると 44〜 $54 \mathrm{mg} \%$ を示したが，それ以 前恃各月とも 70 80 $\mathrm{mg} \%$ 台の高い値であった。

(2) 果肉中のフラホンイド

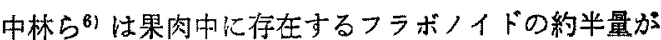
可溶型であり，それが果汁中に移行すると報じているの で，これを考虑し果肉中のフラボノイド量を検討した結 果，いずれも $100 \mathrm{mg} \%$ 以上の值で，多いむのでは 300 $\mathrm{mg} \%$ 前後のものがあった。もっとも少ない変化を持つ むのに T.G. 186，422，津森，434があり，これらはい ずれも中生柑に属し，最高 $130 \mathrm{mg} \%$ 以下で，これにつ ぐものに早生柑の岡辰，22，また，中生柑では秘知，柑 試，1，吉村，62，晚生柑では野村，大川がありこれら の最高量は $145 \mathrm{mg} \%$ 以下である。

また，果肉中のフラポノイド量は過熟期に入るといず れむ下る傾向があり，2月において $200 \mathrm{mg} \%$ 前後ある ものでも 5 月に入ると $100 \mathrm{mg} \%$ 以下の值になるるのが ある。
第 8 表 原木および実生のフラボノイド量

\begin{tabular}{|c|c|c|c|c|}
\hline $\begin{array}{l}\text { 試料 } \\
\text { 番号 }\end{array}$ & $\begin{array}{l}\text { 探双場 所 } \\
\text { および所有者 }\end{array}$ & 酸度\% & 糖屈折度 & $\begin{array}{c}\text { 果肉中の } \\
\text { ナリンジ } \\
ン \text { 量 } \\
\mathrm{mg} \%\end{array}$ \\
\hline 1 & 大日比，原木 & 3. 20 & 10.5 & 237.8 \\
\hline 2 & 大日比, 上利, 実生 & 2.50 & 9.7 & 260.0 \\
\hline 3 & 同 & 3.27 & 10.1 & 273.8 \\
\hline 4 & 同 & 0 & 9.1 & 262.0 \\
\hline 5 & 大日比,三輸，実生 & & 9.6 & 237.8 \\
\hline 6 & 大日比，山田，実生 & 6 & 10.6 & 315.0 \\
\hline 7 & 大日比, 稲岡, 実生 & 2.73 & 9.4 & 116.0 \\
\hline 8 & 同 & 2.62 & 8.6 & 196.3 \\
\hline 9 & 大日比，木下，実生 & 2.62 & 10.2 & 252.5 \\
\hline 10 & 大日比,三鐱, 実生 & 3.84 & 9.7 & 460.0 \\
\hline 11 & 同 & 4. 16 & 10.3 & 395.0 \\
\hline
\end{tabular}

注：山口県大津郡青海島の夏だいだい。 (1962年 3 月 8 日調査)

山口県大津郡青海島に保存される夏だいだい原木およ びその付近にある実生のものについて (第 8 表) 1962年 3月8日に果肉中のフラボノイド量を調查した結果，本 実験に供した俱良柔統に比し，いずれも非常に多く，原 木 $237 \mathrm{mg} \%$ ，実生のもので最高 $460 \mathrm{mg} \%$ ，最低 $116 \mathrm{mg}$ $\%$ て 200 300 mg\% のものが大半であった。

(3) 果肉と擦汁中に利けるフラボノイドの比率 果肉中のフラポノイド量に対する摍汁中のフラボノイ ド量の比率については，第 9 表に示すとおり $30 \sim 60 \%$ の間であり，その変化のもっとあ少ないもの性小，滝 原, T.G. 186，岡辰であり，もっとす変化のはぼしいむ のにB.1, 吉村, 谷川，大川があった。果肉中のフラポ ノイド量と㜔汁中のフラボノイド量との間に，必ずしる 
第 9 表 果肉に対する㩑汁中のフラボノイド量比率

\begin{tabular}{|c|c|c|c|c|c|c|c|c|c|c|}
\hline \multirow{2}{*}{ 熟期区分 } & \multirow{2}{*}{ 系統名 } & \multirow{2}{*}{ 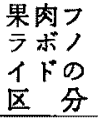 } & \multicolumn{3}{|c|}{ フラポノイド量比率 } & \multirow{2}{*}{ 系統名 } & \multirow{2}{*}{$\begin{array}{l}\text { 果肉7 } \\
\text { ラホボ } \\
1 \text { ドの } \\
\text { 区 分 } \\
\end{array}$} & \multicolumn{3}{|c|}{ フラボノイド量比率 } \\
\hline & & & 2 月 & 4 月 & 5 月 & & & 2 月 & 4 月 & 5 月 \\
\hline \multirow{3}{*}{ 早生柑 } & 12 & $\mathrm{D}$ & 39.4 & 42.4 & - & 川野系 & $D$ & 40.5 & 46.2 & - \\
\hline & B. 1 & D & 45.5 & 36.3 & 56.9 & 岡 辰 & B & 46.9 & 43.2 & 39.2 \\
\hline & 1. D & D & 51.5 & 45.5 & 52.3 & A. 1 & D & 52.2 & 47.0 & 43.7 \\
\hline \multirow{14}{*}{ 中生柑 } & 409 & $\mathrm{D}$ & 45.8 & 30.7 & 31.0 & 吉 村 & B & 29.6 & 52.3 & 42.3 \\
\hline & 302 & $\mathrm{D}$ & 40.8 & 44.8 & - & 福 田 & D & 42.7 & 32.4 & 49.2 \\
\hline & 422 & A & 49.1 & 40.6 & 45.1 & 0.186 & C & 44.0 & 45.5 & 42.5 \\
\hline & 21 & $\mathrm{D}$ & 45.5 & 47.0 & 45.6 & 3 & $\mathrm{C}$ & 42.5 & 46.3 & 52.1 \\
\hline & M. 186 & C & 44.3 & 51.4 & 45.1 & 396 & D & 42.8 & 43.7 & 41.2 \\
\hline & 380 & C & 42.2 & 45.8 & - & 447 & $\mathrm{D}$ & 37.0 & 53.2 & 45.3 \\
\hline & 434 & A & 48.3 & 47.7 & 41.6 & T. G. & A & 50.0 & 47.0 & 45.4 \\
\hline & 436 & D & 61.5 & 49.7 & 51.5 & $\begin{array}{l}100 \\
142\end{array}$ & D & 36.4 & 44.0 & 45.6 \\
\hline & 小野村 & D & 41.6 & 50.9 & 39.6 & 188 & D & 43.2 & 42.2 & 48. 3 \\
\hline & 2 & D & 37.1 & 49.3 & 29.1 & 285 & $\mathrm{D}$ & 48.0 & 44.1 & 46.5 \\
\hline & 小 林 & C & 41.2 & 41.7 & 42.3 & 愛 知 & B & 42.0 & 51.4 & 43.2 \\
\hline & 62 & B & 52.2 & 45.3 & 39.6 & 柑試. 1 & B & 49.0 & 49.1 & 40.3 \\
\hline & 211 & D & 41.1 & 53.0 & 46.4 & 津 森 & A & 57.9 & 47.2 & 39.2 \\
\hline & 304 & D & 38.1 & 42.1 & 46.2 & & & & & \\
\hline \multirow{4}{*}{ 晚生柑 } & 22 & B & 47.2 & 48.6 & 40.4 & 滝 原 & $\mathrm{C}$ & 44.5 & 48.6 & 49.4 \\
\hline & M. 167 & C & 48.0 & 37.0 & 40.4 & 谷 川 & D & 26.2 & 45.6 & 38.4 \\
\hline & 大川 & B & 45.8 & 63.8 & 39.6 & 野 村 & B & 48.5 & 46.7 & 36.7 \\
\hline & 在来種 & D & 30.9 & 36.9 & 41.9 & & & & & \\
\hline
\end{tabular}

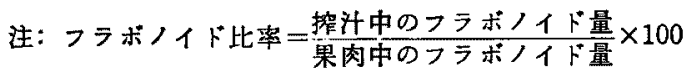

\begin{tabular}{cc|cccc}
\hline 果肉フラボノイド量の区分 & $125-135 \mathrm{mg} \%$ & $136-145 \mathrm{mg} \%$ & $146-155 \mathrm{mg} \%$ & $156 \mathrm{mg} \%$ 以上 \\
\hline 符 & 号 & A & B & C & D \\
\hline
\end{tabular}

正の相関ヶ係は見られない。これはフラボノイドが一部 は果肉中に存在する蛋白質その他の高分子物質と結合し て存在するためと考元られる。

すなわち、ナリンギンの同族体であるへスペリジン は，結晶として取り出すと水に不溶型であるが，組織中 においては蛋白質と結合して複合体をつくり，可溶型を 保っていると考えられ，さらに，結合蛋白質の構造変化に よって不溶型にもなることについて，とくにその蛋白質 親水基が大きい関係をもつことをWAWRA ${ }^{121}$, 吉野13!，

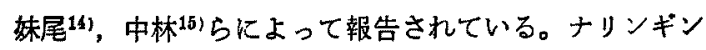
の場合も同様なことが推定され，果肉中の蛋白質など高 分子物質の状態により，控汁中のフラボノイド量が変っ てくるものと思われ，ての点について今後さらに検討の 必要があるが，加工条件としては果肉および搾汁中の可
溶性フラボノイド量が少ない系統が望ましい。この点よ り見ると中生相の 422，434，津森，T.G.186などがその 条件に適合し，他の㩁汁率，種子数なども大体に満足で きるものと考点られるので，今後さらにこれらの系統の リモノイドや苦味量の地域差など，諸性質をくわしく追 究する必要がある。

\section{要約}

夏だいだいの系統 41 種について，加工に関倸する条 件として苦昧 (フシボノイド), 熟期, 種子数, 果汁歩 合を検討した。

（1）熟期については 41 系統のう弓，1２月を早 生柑，3〜4 月を中生柑，5 月以降を晚生柑とし，それ ぞれ 6，29，7系統に区分された。 
（2）㩁汁歩合任早生柑で 1 系統, 中生柑で 4 系統, 婏生相で 2 系統優秀なるのを見い出した。また，5月に おいて果汁の急減を示すものが多く，晚生柑にはこの傾 向が少ない。

（3）果肉歩合壮各系統間に大差なく，120攵方薄皮 で高歩合を示した。種子数は脕生柑に多く，早生柑に少 ない傾向が見られた。

（4）果肉就よび搾汁中のフラボノイド量がとくに少 ない系統は，いずれも中生柑化認められ，また全般的比 は過熟期に入ると減少する傾向が強い。

（5）総合的な面で，各条件を満す系統は見られない が，それぞれ特徽をむち，大体満足できる系統として T.G. 186，422，434，津森肪西る。

(6) 果肉中のフラボノイドに対する搾汁中のフラボ ノイドの比率を見ると，その関倸に必ずしる正の相関々 係は見られない。これ性果肉中のたえ济く質その他高分 子物質以よるものであることが予想されるので，苦味量 の地域的な差とともにその状態を良系統について，今後 研究し，検討を加える必要がある。

本実験は経費の一部を山口県農業試験場の委託研究費 によった。記して謝意を表する。な和理々御指導戴いた 山口大学農学部野村男次博士と多大の便宜を与えられた 薬師寺虎雄場長ならびに県農試野原技師に媣謝の意を表 するとともに，御協力頂いた本試駼場職員各位に対乙厚
く御礼申し上げる。

文献

1）野老山香：日化，79，(3)，314（1958）。

2) Kefford, J.F., Chander, B.V. and Lynch, L.J.: Food Pres., 12, 26 (1952).

3) Kefrord, J. F. and Chandler, B.V.: Australian J. Agr. Research, 12, 56 (1961).

4）野村男次：日本食品工業学会第 9 回大会発表 (1957年5月10日).

5）野村男次：要蜜相の化学的研究，第 1 号，山口大 学農学部学術報告別冊, $41 \sim 46$ (1955).

6）中林敏郎：食品工誌，9，(1)，28(1962).

7) 福本寿一郎：日本食品工業学会, 第 9 回シンポシ ウム筷演集, p. 28 (1962).

8）山口県農業試験場：夏橙優良系統選拔試驗成績, 第 1 報 (1951)

9) Davis, W.D.: Anal. Chem., 19, 476 (1947).

10）會岡唯行 - 松本和夫 - 閏屋一臣 - 向井 武：果樹 園芸，15，(6)，17 (1962).

11）三島恭一：果実日本，16，(9)，40 (1961).

12) Wawra, C.Z. and WeBb, J.L.: Science, 96, 2941 (1942).

13）吉野孝光・岩田幸夫：農産技研誌， 5，(3)，119 (1958).

14）妹尾芳郎：農産技研誌，7，(3)，129（1960）。

15）中林敏郎 - 水上 豊 - 本田初雄 - 古井広岸：農産 技研誌，6，(6)，261 (1959)。

(1962年 7 月 18 日受理）

\section{製パンにおけるプロテアーゼの利用に 関する研 究（第 1 報）}

各種プロテアーゼのたんぱく分解力と製パンに掠よばす影響

佐藤友太郎*・岡田経子*渡辺修*

小麦粉のプロテフーゼは，製パンにとって少量は必要 であるが，多すぎると生地を軟化させるので望むしくな いということは古くからいわれているところである。ブ
ロム酸カリのような酸化郕の粉質改良作用は，このプロ テフーゼ作用を抑制するにあると強調する説もあるの は、このことを襄書きするるのである。

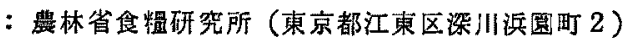

The Utilization of Protease in Baking. Part. I. The proteolytic activities and the effects on baking of various kinds of protease. By Tomotaro Sato, Tsuneko Orada and Osamu Watanabe. 